commercial cultivars are given in Table 1.

Each year, a small percentage of 'Applethorpe Earlidel' fruit $(<5 \%)$ is observed with infection of dry moldy core (Alternaria spp.), but this cultivar is not as susceptible as 'Delicious' (25\% infection).

'Applethorpe Earlidel' has moderate resistance to apple scab [Venturia inaegualis (Cke.) Wint.] and powdery mildew [Podosphaera leucotricha (En. and Ev.) Salm.], and infection has been observed only under conditions of high disease pressure. The sus- ceptibility to firelight [Erwinia amylovora (Burr.) Winslow et al.] is unknown as this disease does not occur in Australia.

\section{Availability}

Limited. quantities of budwood are available for testing and commercial propagation from the Queensland Department of Primary Industries, Granite Belt Horticultural Research Station, Applethorpe, 4378, Queensland, Australia. 'Applethorpe Earlidel' is not a patented cultivar. Budwood source trees have not been virus-indexed, but were propagated from the original seedling using virus-tested clonal MM. 106 and 'Northern Spy' rootstock.

\section{Literature Cited}

Royal Horticultural Society. 1966. RHS colour chart. The Royal Horticultural Society, London.

Watkins, R. and R. Smith. 1982. Descriptor list for apples (Malus). International Board for Plant Genetic Resources, Rome.

\title{
CU-R89: Red Kidney Bean Breeding Line Resistant to Bean Yellow Mosaic Virus
}

\author{
B. Scully ${ }^{1}$ \\ Texas Agricultural Experiment Station, Weslaco, TX 78596-8399 \\ R. Provvidenti ${ }^{2}$ \\ New York State Agricultural Experiment Station, Cornell University, \\ Geneva, NY 14456
}

D.E. Halseth ${ }^{3}$

Department of Vegetable Crops, Cornell University, Ithaca, NY 14853

\section{D.H. Wallace ${ }^{4}$}

Department of Plant Breeding and Biometry, Cornell University, Ithaca, NY 14853

Additional index words. By-2 gene, BYMV resistance, Phaseolus vulgaris, vegetable breeding

Bean yellow mosaic virus (BYMV) is one of the most important virus diseases of beans in New York State. Susceptible plants exhibit symptoms including yellow mosaic, leaf malformation, and stunting. CU-R89 resulted from a breeding program conducted to incorporate BYMV resistance into 'Ruddy' (Sandsted, 1982), a light red kidney bean. Resistance was developed using the single

Received for publication 15 May 1989. This research was supported by the Depts. of Vegetable Crops, Plant Breeding and Biometry, and Plant Pathology, Cornell Univ., and USAID Title XII Bean/Cowpea CRSP. We gratefully acknowledge the assistance of D. Benscher, J.G. Doss, W.L. Hymes, and L. Montorossa-Teñas. Plant Breeding and Biometry paper no. 782. The cost of publishing this paper was defrayed in part by the payment of page charges. Under postal regulations, this paper therefore must be hereby marked advertisement solely to indicate this fact.

'Assistant Professor (formerly Graduate Research Assistant, Dept. of Plant Breeding and Biometry, Cornell Univ., Ithaca, N.Y.).

${ }^{2}$ Liberty Hyde Bailey Professor of Plant Pathology.

Assistant Professor.

${ }^{4}$ Professor. dominant gene $B y-2$ that was first transferred into Phaseolus vulgaris L. through an interspecific cross with a scarlet runner bean (Phaseolus coccineus L.) (Dickson and Natti, 1968). As daily mean temperatures rise above $30 \mathrm{C}$, the $B y-2$ gene can cause infected plants to develop systemic 'necrosis. This breeding line is intended for use in Central and North American breeding programs, or wherever BYMV occurs.

\section{Origin}

The backcross method was used to develop CU-R89, with 'Ruddy' as the recurrent parent and B-21 as the donor parent providing the By-2 gene (Fig.1). B-21 is a black bean breeding line developed from a series of backcrosses, with 'Black Turtle-1' as the recurrent parent and crossed with the progeny of a $P$. vulgaris $\mathrm{L} . \times P$. coccineus L. cross (Dickson and Natti, 1968; Provvidenti, 1983; Provvidenti et al., 1989). 'Ruddy' was the female parent for three generations, but failed as the female parent when crossed in the BC-2 generation (Fig. 1). In the BC-3 generation, 'Ruddy' was again used as the female, and the progenies from each pollination were bulked in BC-4. In each backcross generation, 20 or more plants were mechanically inoculated with BYMV (Strain \#1) (Hagedom and Walker, 1950) at the primary leaf stage to identify progeny with the By-2 gene. At the end of the crossing scheme, a progeny test identified the homozygous genotypes in $\mathrm{BC}-4 \mathrm{~F}_{3}$; resistance was confirmed in $\mathrm{BC}-4 \mathrm{~F}_{4}$. CU-R89 is derived from progeny of the $\mathrm{BC}-4 \mathrm{~F}_{3}$.

\section{Description}

In the environment of northern New York, CU-R89 is a multiple-stemmed plant with a determinate growth habit. Plants are bushy, 40 to $50 \mathrm{~cm}$ high, less upright than 'Redkloud', and commonly develop six to eight main-stem nodes. The time to maturity is 85 to 95 days, the same as 'Ruddy', and plants naturally defoliate at maturity. Flowers are pale lavender to rose-purple, but the stems and petioles lack this pigment. The pods are up to $15 \mathrm{~cm}$ long, fibrous and indehiscent with four to eight seeds. Pods dry to a tan color. The seedcoat. color is an excellent light

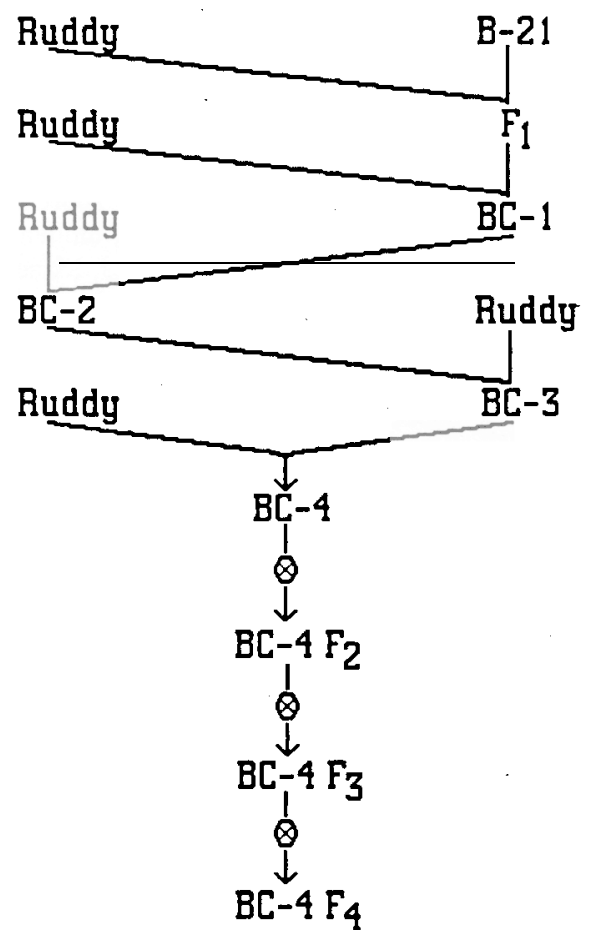

Fig. 1. Pedigree of CU-R89. 
Table 1. Seed yield of CU-R89 compared to 'Ruddy' at Freeville and Stanley, N.Y. in 1988.

\begin{tabular}{|c|c|c|c|}
\hline \multirow[b]{2}{*}{ Site } & \multicolumn{2}{|c|}{$\begin{array}{l}\text { Mean seed yield } \\
\text { (g/plot) }\end{array}$} & \multirow{2}{*}{$\begin{array}{c}t \\
\text { statistic }\end{array}$} \\
\hline & CU-R89 & Ruddy & \\
\hline Freeville & 848.8 & 1180.3 & $2.8^{\mathrm{NS}}$ \\
\hline Stanley & 878.5 & 973.5 & $0.58^{\mathrm{NS}}$ \\
\hline Means & 858.7 & 1111.3 & $2.5^{\mathrm{Ns}}$ \\
\hline
\end{tabular}

${ }^{\mathrm{NS}}$ Not significant at $\mathrm{P} \leq 0.05$.

red. Seeds are kidney-shaped, with a 100seed weight of 47 to $55 \mathrm{~g}$. Like 'Ruddy', CU-R89 has excellent color retention over time and cooks quickly. CU-R89 was screened in $\mathrm{BC}-4 \mathrm{~F}_{4}$ for the I gene, which confers resistance to bean common mosaic virus (pathotype 'NY 15') (Provvidenti, 1987). It is susceptible to halo blight [Psuedomonas phaseolicola (Burk.) Dews] and common blight [Xanthomonas phaseoli (E.F. Smith) Dews] and at least one strain of anthracnose [Colletotrichum lindemuthianum (Sacc. \& Magn.) Scrib.].

CU-R89 and 'Ruddy' were compared in state trials at Freeville and Stanley, N.Y. Yields of 'Ruddy' were not significantly different from CU-R89 at either site or over sites (Table 1). Because CU-R89 is nearly isogenic with 'Ruddy', it is suitable for evaluation as a BYMV-resistant replacement for 'Ruddy'.

\section{Availability}

Small quantities of CU-R89 seed are available from D.H.W.

\section{Literature Cited}

Dickson, M.H. and J.J. Natti. 1968. Inheritance of resistance of Phaseolus vulgaris to bean yellow mosaic virus. Phytopathology 58:1450.

Hagedorn, D.J. and J.C. Walker. 1950. The relationship of bean virus 2 to pea mosaic in Wisconsin. Phytopathology 40:684-698.

Provvidenti, R. 1983. Two useful selections of the bean cultivar 'Black Turtle Soup' for virus identification. Annu. Rpt. Bean Imp. Coop. 26:7375.

Provvidenti, R. 1987. List of genes in Phaseolus vulgaris for resistance to viruses. Annu. Rpt. Bean Imp. Coop. 30:1-4.

Provvidenti, R., B. Scully, D.E. Halseth, and D.H. Wallace. 1989. B-21: A dry black bean breeding line with multiple virus resistance. HortScience 24:1049.

Sandsted, R.F. 1982. 'Ruddy': A new light red kidney variety. Dept. Veg. Crops Mimeo. Ser. VC-271. Cornell Univ., Ithaca, N.Y.

HORTSCIENCE 25(2):236-237. 1990.

\title{
'Greenthumb Peppermint' Azalea
}

\author{
T.E. Bilderback ${ }^{1}$, D.J. Cagle ${ }^{2}$, and P.R. Fantz ${ }^{3}$ \\ North Carolina State University, Raleigh, NC 27695
}

Additional index words. azalea breeding, Rhododendron, ornamental breeding

Rhododendron L. 'Greenthumb Peppermint' is a mid- to late-blooming evergreen azalea with showy 7 - to $8.3-\mathrm{cm}$, semidouble, hose-in-hose flowers (Fig. 1). Flowers commonly are pinkish in hue with white margins and a soft purplish-pink inner pattern that is variable in its expression. The unusual condition of plants typically bearing one or two sports with either strong purplish-pink or white flowers (Fig. 2), the floriferous flowers, and the degree of cold hardiness (zones 7 to 8 ) were the objectives leading to selection of 'Greenthumb Peppermint',

\section{Origin}

'Greenthumb Peppermint' is a sport selected by D.J.C. in 1980 from an unidentified azalea growing in the yard of B.J. Maness of Asheboro,. N.C. Propagules from the

Received for publication 17 Aug. 1988. Paper no. 11747 of the Journal Series of the North Carolina Agricultural Research Service, Raleigh, NC 276957643. The use of nursery and trade names in this publication does not imply endorsement by the North Carolina Agricultural Research Service of the nursery or the products mentioned, nor criticism of similar ones not mentioned. The cost of publishing this paper was defrayed in part by the payment of page charges. Under postal regulations, this paper therefore must be hereby marked advertisement solely to indicate this fact.

'Associate Professor, Dept. of Horticultural Science, Box 7609, North Carolina State Univ., Raleigh, NC 27695 .

Owner, Greenthumb Nursery, Rte. 2, Box 110 , Seagrove, NC 27341.

Associate Professor, Dept. of Horticultural Science. original tissue and the sport were grown and evaluated for the past 8 years by Greenthumb Nursery, Seagrove, N.C.

The original parent plant is dead. Clones from the parent plant tissue (Fig. 3) bear 5to $6.4-\mathrm{cm}$ double, hose-in-hose flowers that are strong purplish-pink, Munsell 5 RP 5/10 (Wilde and Voigt, 1977), correlating most closely with Royal Horticulture Society (RHS) colour chart number 55B (Huse and Kelly, 1984).

\section{Description}

'Greenthumb Peppermint' is an erect shrub with branches ascending and spreading. Stems are sympodial, growing 4 to $10 \mathrm{~cm}$ per year. Juvenile twigs are $\approx 2-2.5 \mathrm{~mm}$ in diameter and densely strigose, with deltoid-linear trichomes that are white, ascending-adpressed, 1-2 $\mathrm{mm}$ long, and becoming darkened on the second year's growth. Leaves are crowded toward the apex, scattered strigose on both surfaces, ciliolate, and strigose below on the midrib and less so on major veins, with trichomes $\approx 0.7-2 \mathrm{~mm}$ long. Summer leaves are thin coriaceous, dark green above, pale below, somewhat glossy, broadly elliptic to ovate-elliptic to oblong-elliptic, broadly obtuse, mucronate, cuneate to subrotund, and $2-5 \times 4-9 \mathrm{~cm}$. Winter leaves are thickmembraneous, elliptic, broadly acute, mucronate, cuneate, and 1.5-3 × 3-6 cm. Petioles are 6-12 $\mathrm{mm}$ long. Inflorescences are axillary and sessile, bearing two flowers. Bracts are spreading, broad ovate to suborbicular, convex with medially rounded, strigose keel, and 8-11 $\times 9-13 \mathrm{~mm}$. Pedicels are pilose-strigose and $0.8-1.5 \mathrm{~cm}$ long. Flowers (see front cover of this issue of HortScience) are semidouble, hose-in-hose, $7-9.5 \mathrm{~cm}$ in diameter, pale pink in hue with white margins and pale purplish-pink centers, variegated in pattern, and occasionally white or dark maroon pink on sports. The

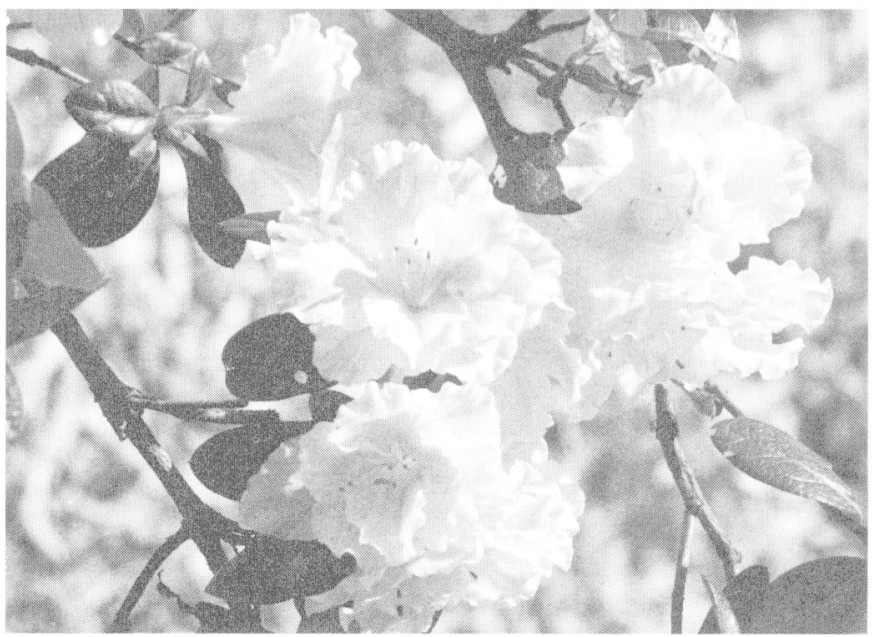

Fig. 1. Semidouble, hose-in-hose flowers of 'Greenthumb Peppermint'. 